Article

\title{
Fitness of Selected Indigenous Saccharomyces cerevisiae Strains for White Piceno DOC Wines Production
}

\author{
Alice Agarbati, Laura Canonico, Maurizio Ciani ${ }^{(1)}$ and Francesca Comitini * \\ Dipartimento di Scienze della Vita e dell'Ambiente (DiSVA), Università Politecnica delle Marche, \\ Via Brecce Bianche, 60131 Ancona, Italy; a.agarbati@pm.univpm.it (A.A.); 1.canonico@univpm.it (L.C.); \\ m.ciani@univpm.it (M.C.) \\ * Correspondence: f.comitini@univpm.it
}

Received: 11 March 2018; Accepted: 29 May 2018; Published: 31 May 2018

\begin{abstract}
Verdicchio, Passerina and Pecorino are native grape cultivars of the Marche region, cultivated in winemaking area of Ascoli Piceno, in central Italy. In particular, Passerina and Pecorino varieties have been abandoned and forgotten for a long time and only in recent years are rediscovered and appreciated. Here, two indigenous yeasts, isolated from grapes of Verdicchio and Pecorino varieties and identified as Saccharomyces cerevisiae, were evaluated and compared with commercial starters cultures widely used for the vinification of Piceno DOC (Denominazione Origine Controllata) area at industrial scale. A polyphasic approach, including yeast genotyping, phenotypic traits evaluation and fermentative performance in natural grape juice, was applied to evaluate the fitness of strains. Using interdelta primers, the two selected cultures showed a unique profile while the results of microvinifications showed that both indigenous strains exhibited good enological parameters and fermentative aptitude comparable with that shown by commercial strains used as controls. The profile of volatile compounds of wines of indigenous strains was characterized by a significant high production of isoamyl acetate and ethyl esters at $22{ }^{\circ} \mathrm{C}$ and phenyl ethyl acetate at $16{ }^{\circ} \mathrm{C}$. Overall results indicate that the two indigenous selected yeasts showed a genetic and phenotypic specificity and they could be profitably used to characterize the Piceno DOC area wines.
\end{abstract}

Keywords: Saccharomyces cerevisiae; indigenous yeast; wine; starters

\section{Introduction}

The territory of Piceno is one of the areas with the greatest wine vocation within Marche region, in the center of Italy. The Piceno territory was initially known for its red wines, the first to obtain national awards, progressively combined by native white wines, rediscovered by local producers and winemakers who reassessed their potential. In particular, the Offida DOCG (Denominazione Origine Controllata Garantita) wines refer to Pecorino and Passerina varieties that originate wines characterized by a straw yellow color with greenish and yellowish reflections, respectively, a good level of acidity, smell of floral notes (white flowers), fruity pineapple, hints of anise and sage, taste are fresh and mineral sapid. Fermentation of these white wines are generally carried out at low temperatures (from $16{ }^{\circ} \mathrm{C}$ to $22^{\circ} \mathrm{C}$ ). In the last years, as reported by "Consorziovinipiceni" [1], Passerina wines have undergone the greatest increase in the sale of bottles in Italy in 2015. In particular, the official data showed that Passerina and Pecorino increased by $34.2 \%$ and $19.9 \%$, respectively.

Quality perception is a combination of both sensory and chemical approaches that influence wine experts and consumers. The aroma of wine is a combination of volatile compounds originating from grapes (varietal aromas), secondary products formed during the wine fermentation (fermentative 
aromas) and aging (post-fermentative aromas) [2]. The main volatile compounds are produced by yeast during alcoholic fermentation, and significantly impact the flavor and overall quality of wines [3].

Molina et al. [4] evaluated the influence of fermentation temperature on the production of yeast-derived aroma compounds together with the expression of genes involved, during the fermentation of a defined must at 15 and $28^{\circ} \mathrm{C}$. They found that the production of volatile aroma compounds varied according to yeast growth stage. In particular, higher concentrations of compounds related to fresh and fruity aromas were found at low temperature, while higher concentrations of flowery related aroma compounds were found at $28^{\circ} \mathrm{C}$. In addition, Torijia et al. [5] demonstrated that low temperatures restricted yeast growth and lengthened the fermentations. In particular, low temperature alcoholic fermentations are becoming more frequent due to the wish to produce wines with more pronounced aromatic profiles. The yeast influence on wine aroma is not only species-dependent but relevant variations are also showed at strain level [6,7]. In this regard, each wine yeast strain produces different aroma compounds, higher alcohols, acetate esters, ethyl esters and aldehydes that characterize the final wine bouquet [4]. Indeed, different strains of S. cerevisiae can metabolize flavor active compounds that characterized different grape varieties to produce volatile compounds [8]. For this reason, the choice of wine yeast is crucial for the development of the desired wine style. On the other hand, after the wide diffusion of the use of selected S. cerevisiae starter cultures, many studies were conducted with the aim to select, from various habitats, yeast strains with physiological characteristics functional to be used as commercial starter. In recent years, there is increasing interest among winemakers to select local strains with the aim to select starter cultures potentially well adapted to specific grape must reflecting the biodiversity of a given region, which support the notion that specific indigenous yeast strains can be associated with a "terroir" [9-13]. The use of indigenous yeast strains that possess suitable oenological characteristics and also closely related to the territory of vineyard, is desirable for their better adaptation to the environmental conditions and may contribute to the maintenance of the "typical" sensory properties of the wines of each specific region.

On this basis, the aim of this work was to characterize two selected indigenous yeast strains isolated from vineyards of Piceno DOC area and to evaluate the fermentative fitness in comparison with the commercial starter strains widely used for the production of Piceno DOC wines.

\section{Materials and Methods}

\subsection{Yeast Strains}

Ten different commercial S. cerevisiae starter strains were used to compare the genomic differences at strain level of two indigenous $S$. cerevisiae (Pe1 and G4). The commercial dry starter used were: Lalvin EC1118, Lalvin ICV OKAY, NEM, Enoferm BDX, Uvaferm CM, BC, CEG, and VRB YSEO (Lallemand Inc., Toulouse, France); VIN13 (Anchor Wine Yeast, Cape Town, South Africa); and Zymaflore F15 (Laffort, Bordeaux Cedex, France). All these dry yeasts were rehydrated following the manufacture instructions and the isolated pure cultures were used for genetic and physiological evaluation essays. For the fermentation trials, three starter cultures, VIN13, OKAY and EC1118, were used as control strains.

The selected indigenous S. cerevisiae (Pe1 and G4) came from Pecorino and Verdicchio grapes in the Offida DOC area. These yeasts were previously identified by D1 and D2 26S-DNA sequence [14].

All of the yeast strains were maintained at $4{ }^{\circ} \mathrm{C}$ for short-term storage on yeast extract-peptonedextrose (YPD) agar medium (Oxoid, Basingstoke, UK) and for long-term storage in YPD broth supplemented with $80 \%(w / v)$ glycerol at $-80^{\circ} \mathrm{C}$.

\subsection{Molecular Identification and Characterization of the S. cerevisiae Isolates}

Pure yeast cultures of all commercial S. cerevisiae and two indigenous selected culture were pre-grown on YPD agar at $25{ }^{\circ} \mathrm{C}$ for 3-4 days. The cells were then transferred to screwcap tubes with 
$5 \mu \mathrm{L}$ of water molecular biology grade and the DNA was extracted at $95^{\circ} \mathrm{C}$ for $10 \mathrm{~min}$ in Biorad Thermal Cycler [15]. PCR amplifications were carried out as described by Legras and Karst [16] using primer delta 2 (5'-GTGGATTTTTTATTCCAAC-3) and primer delta 12 (5'-TCAACAATGGAATCCCAAC-3').

The amplification reactions were performed with a Biorad Thermal Cycler, using the following programme: $4 \mathrm{~min}$ at $95^{\circ} \mathrm{C}$, followed by 35 cycles of $30 \mathrm{~s}$ at $95^{\circ} \mathrm{C}, 30 \mathrm{~s}$ at $46^{\circ} \mathrm{C}$, and $90 \mathrm{~s}$ at $72{ }^{\circ} \mathrm{C}$, and the final extension at $72{ }^{\circ} \mathrm{C}$ for $10 \mathrm{~min}$. Amplification products were separated by electrophoresis on $1.5 \%(w / v)$ agarose gels submitted to $100 \mathrm{~V}$ for $1 \mathrm{~h}$ in $0.5 \times$ TBE buffer.

\subsection{Fermentation Power Assay (Maximum Ethanol Production)}

To determine the fermentation power of OKAY, VIN13, EC1118, Pe1 and G4, grape juice coming from vintage 2016 was adjusted to 30\% sugar content with sucrose (Carlo Erba, reagents S.r.1., Comaredo, Milano). The trials were carried out on $70 \mathrm{~mL}$ of pasteurized Verdicchio grape juice at $25{ }^{\circ} \mathrm{C}$ under static condition in triplicate. The pasteurization process was carried out at $100{ }^{\circ} \mathrm{C}$ for $10 \mathrm{~min}$. All strains were pre-cultured in modified YPD $(0.5 \% w / v$ yeast extract, $2 \% w / v$ glucose, $0.1 \% w / v$ peptone) for 1 day at $25{ }^{\circ} \mathrm{C}$ in an orbital shaker (rotation, $150 \mathrm{rpm}$ ). The cells were used to inoculate the grape juice at initial concentration of approximately $1 \times 10^{6}$ cells $/ \mathrm{mL}$ for each yeast.

\subsection{Microfermentation Trials}

To evaluate the fermentative aptitudes of the indigenous $S$. cerevisiae strains, two sets of fermentation trials were carried out at different fermentation temperatures $\left(22{ }^{\circ} \mathrm{C}\right.$ and $\left.16{ }^{\circ} \mathrm{C}\right)$ on Verdicchio grape juice coming from vintage 2015. The Verdicchio grape juice had the following main analytical composition: $\mathrm{pH}$ 3.26; initial sugar content $217 \mathrm{~g} / \mathrm{L}$; total acidity $4.53 \mathrm{~g} / \mathrm{L}$; and nitrogen content YAN (111 mg/L). The fermentation trials were carried out in flasks containing $350 \mathrm{~mL}$ of Verdicchio grape juice. The flasks were locked with a Müller valve containing sulfuric acid to allow only $\mathrm{CO}_{2}$ to escape from the system and placed at $22{ }^{\circ} \mathrm{C}$ or $16^{\circ} \mathrm{C}$ in thermostat under static condition in triplicate.

All strains were pre-cultured in modified YPD $(0.5 \% w / v$ yeast extract, $2 \% w / v$ glucose, and $0.1 \% w / v$ peptone) for 1 day at $25{ }^{\circ} \mathrm{C}$ in an orbital shaker (rotation, $150 \mathrm{rpm}$ ). The cells were used to inoculate the grape juice at initial concentration of approximately $1 \times 10^{6}$ cells $/ \mathrm{mL}$ for each yeast. As control strains, VIN13, OKAY and EC1118 were used. The fermentation kinetics were monitored by measuring the weight loss of the flasks due to the $\mathrm{CO}_{2}$ evolution, which was followed to the end of the fermentation (i.e., constant weight for 2 consecutive days).

\subsection{Analytical Procedures}

To determine the glycerol and sugar concentrations, specific enzyme kits (Megazyme International Ireland, Wicklow, Ireland) were used. Ethanol content, volatile acidity and total $\mathrm{SO}_{2}$ were measured using the current analytical methods according to the Official European Union Methods [17]. Ammonium was determined using an enzymatic method (kit no. 112732; Roche Diagnostics, Germany), while the free $\alpha$-amino acids were quantized following the procedures described by Dukes and Butzke [18], using the $o$-phthaldialdehyde/N-acetyl-l-cysteine spectrophotometric assay. Yeast assimilable nitrogen was calculated as the sum of the concentrations of the free $\alpha$-amino acids and the ammonium.

Fermentation power (FP) indicates the maximum amount of ethanol (as $\% v / v)$ in the presence of an excess of sugar. Fermentation vigor (FV) was evaluated as the amount of carbon dioxide produced after 3 days of fermentation [19].

Acetaldehyde, ethyl acetate, n-propanol, isobutanol, amyl and isoamyl alcohols and acetoin, were quantified by direct injection into a gas-liquid chromatography system. Each sample was prepared and analyzed as reported by Canonico et al. [20].

The volatile compounds were determined by solid-phase microextraction (HS-SPME) method. Each sample $(5 \mathrm{~mL})$ was placed in vial containing $1 \mathrm{~g} \mathrm{NaCl}$ closed with a septum-type cap. HS-SPME 
was carried out under magnetic stirring for $10 \mathrm{~min}$ at $25^{\circ} \mathrm{C}$. After this period, an amount of 3-octanol as the internal standard $(1.6 \mathrm{mg} / \mathrm{L})$ was added and the solution was heated to $40^{\circ} \mathrm{C}$ and extracted with a fiber Divinylbenzene/Carboxen/Polydimethylsiloxane (DVB/CAR/PDMS) for 30 min by insertion into the vial headspace. The compounds were desorbed by inserting the fiber into Shimadzu gas chromatograph GC injector for $5 \mathrm{~min}$. A glass capillary column was used: $0.25 \mu \mathrm{m}$ Supelcowax 10 (length, $60 \mathrm{~m}$; internal diameter, $0.32 \mathrm{~mm}$ ). The fiber was insert in split-splitless modes, as reported by Canonico et al. [20].

\subsection{Statistical Analysis}

The experimental data related to wines were elaborated by one-way ANOVA. The means were analyzed using the STATISTICA 7 (Statsoft, Tulsa, OK, USA). The significant differences were determined using Duncan tests, and the data were considered significant if the associated $p$ values were $<0.05$. Principal component analysis (PCA) was used to discriminate among the means of volatile compounds. The PCA was carried out using the Unscrambler 7.5 software (CAMO ASA, Oslo, Norway). The mean data were normalized to neutralize any influence of hidden factors.

\section{Results}

\subsection{Biotyping of the Selected Cultures}

he results of biotyping carried out using interdelta primers are reported in Figure 1. The comparison with ten of the most diffused S. cerevisiae commercial strains widely used during Piceno DOCG fermentations indicated that the indigenous strains Pe1 and G4 showed unique profiles and can be easily distinguished from the other strains.

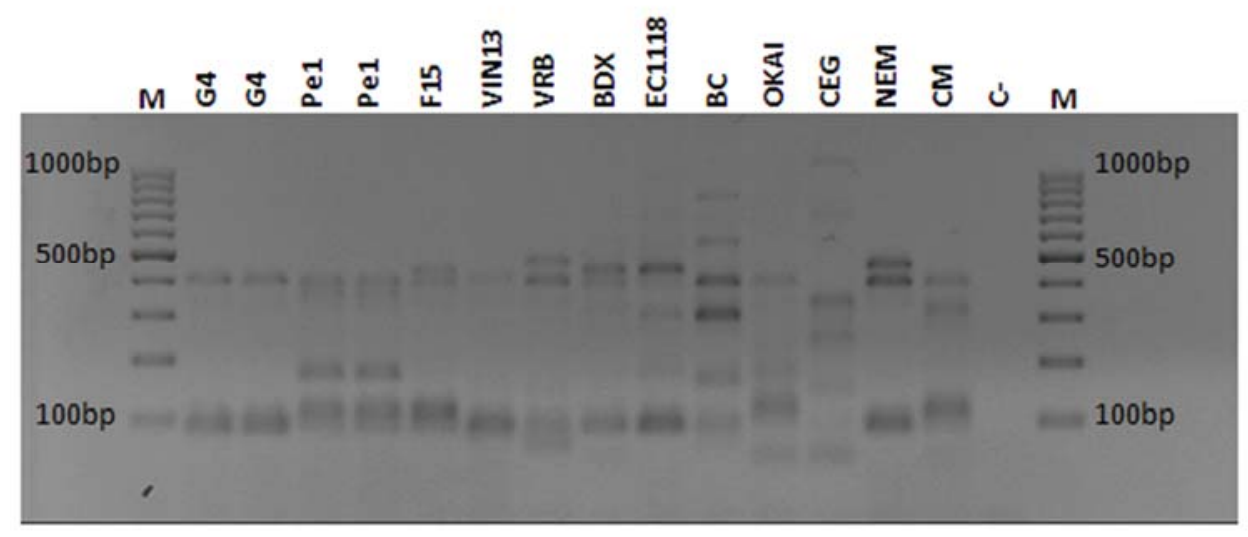

Figure 1. Molecular characterization of commercial and indigenous $S$. cerevisiae. PCR inter- $\delta$ primers were used to amplify the corresponding genes of strains. The representative gel shows the profiles of these selected strains; indigenous strains are reported in duplicate. Lane M: Gene ruler $100 \mathrm{bp}$ (Fermentans), as indicated on the left and right of gel. Lane C-: indicated as negative control.

\subsection{Fermentation Power (FP) and Fermentation Vigour(FV) Test Assay}

Results of microfermentation trials carried out to determine FP (fermentation power) and FV (fermentation vigor) are shown in Table 1. Under the condition tested, VIN13 and EC1118 showed the best performance achieving a FP higher that $14.0 \% v / v$ of ethanol. They were followed by Pe1 with FV of $13.8 \% v / v$, OKAY $(13.0 \% v / v)$ and G4 $(12.2 \% v / v)$ with variable residual sugars. Regarding to the evaluation of FV, the best performance was exhibited by Pe1 ( $4.5 \mathrm{~g}$ evolved by the apparatus in the first three days of fermentation) followed by VIN13 (4.0 g) and the other strains that showed lower FR. Moreover, Figure 2 shows the lower fermentation kinetics of G4 strain in comparison with the other strains tested, while Pe1 exhibited an intermediate behavior between the S. cerevisiae commercial strains. 


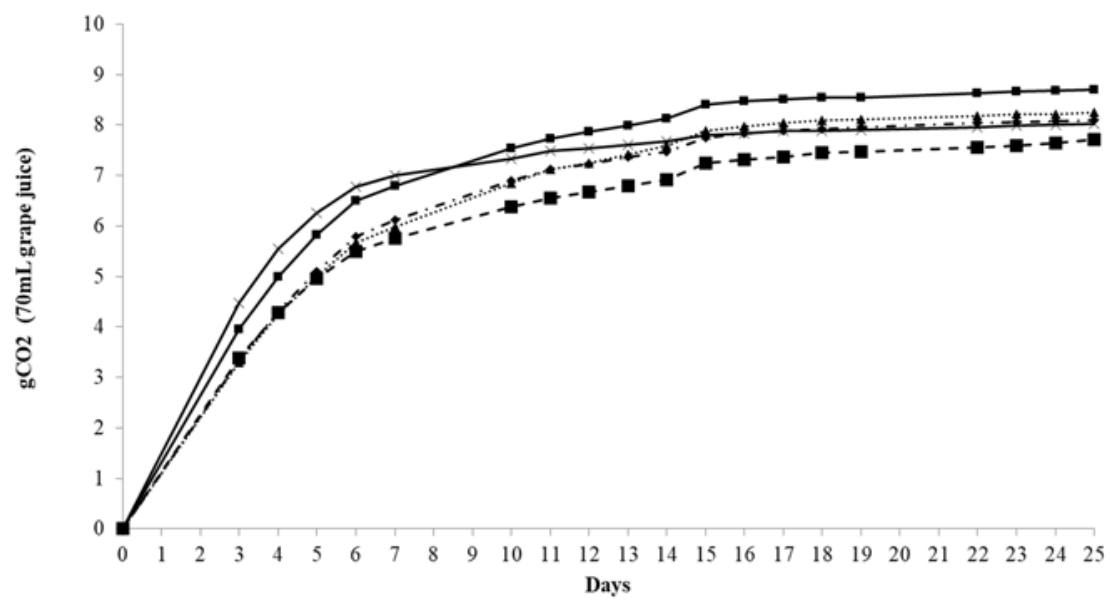

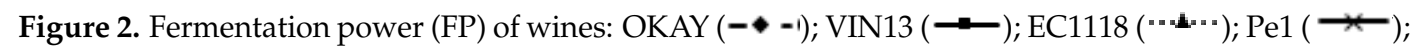
and G4 (-- - *).

Table 1. Fermentation power and fermentation vigor in high sugar Verdicchio grape juice (fermentation power assay).

\begin{tabular}{|c|c|c|c|}
\hline Strains & Ethanol $(\% v / v)$ & Residual Sugar (g/L) & ${ }^{*}$ Fermentation Vigour (g CO $2 / 3$ Days) \\
\hline OKAY & $13.05 \pm 0.27^{c}$ & $24.04 \pm 2.75^{b, c}$ & $3.34 \pm 0.26^{\mathrm{b}}$ \\
\hline VIN13 & $14.34 \pm 0.10^{\mathrm{a}}$ & $7.36 \pm 2.92^{d}$ & $3.95 \pm 0.34^{\mathrm{a}, \mathrm{b}}$ \\
\hline EC1118 & $14.23 \pm 0.07^{\mathrm{a}}$ & $21.09 \pm 0.80^{\mathrm{c}}$ & $3.30 \pm 0.16^{\mathrm{a}}$ \\
\hline Pe1 & $13.78 \pm 0.10^{\mathrm{b}}$ & $27.38 \pm 2.34^{b}$ & $4.47 \pm 0.01^{\mathrm{a}}$ \\
\hline G4 & $12.15 \pm 0.06^{\mathrm{d}}$ & $35.90 \pm 0.21^{\mathrm{a}}$ & $3.38 \pm 0.40^{b}$ \\
\hline
\end{tabular}

* Evaluated at Day 3 of fermentation ( $\mathrm{g}$ of $\mathrm{CO}_{2}$ evolved by $350 \mathrm{~mL}$ of substrate). Data are means \pm standard deviations. Statistical analysis did not include the base wine. Data with different superscript letters $(\mathrm{a}, \mathrm{b}, \mathrm{c}, \mathrm{d})$ within each column are significantly different (Duncan test; $p<0.05$ ).

\subsection{Microfermentation Trials Carried Out at $16{ }^{\circ} \mathrm{C}$ and $22^{\circ} \mathrm{C}$}

The results of fermentation kinetics of microfermentations carried out at $16{ }^{\circ} \mathrm{C}$ and $22{ }^{\circ} \mathrm{C}$ are reported in Figure 3. The data of the fermentation trials carried out at $22{ }^{\circ} \mathrm{C}$ showed comparable fermentation kinetics among all $S$. cerevisiae strains tested, highlighting no differences between the indigenous and commercial strains. Only Pe1, after 16 days of fermentation, exhibited higher fermentation kinetics in comparison with the other strains.

The fermentations carried out at $16{ }^{\circ} \mathrm{C}$ showed slower fermentation kinetics in comparison with the same trails carried out at $22{ }^{\circ} \mathrm{C}$ without relevant differences among the strains tested (31 days instead 22 days at $22{ }^{\circ} \mathrm{C}$ ). However, OKAY showed slower fermentation kinetics in comparison with the other strains. Therefore, in both fermentation conditions, the two indigenous strains exhibited a kinetics comparable to that showed by S. cerevisiae commercial starter strains. 
(a)

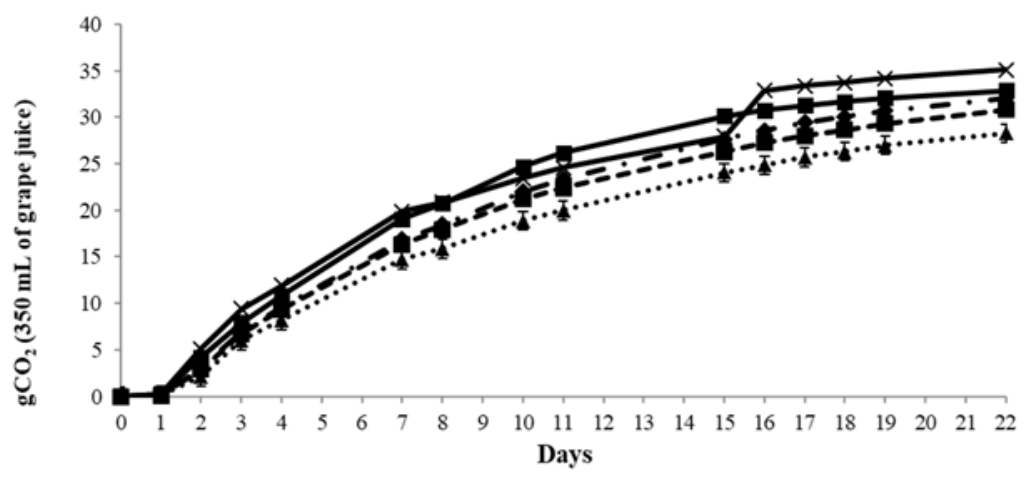

(b)

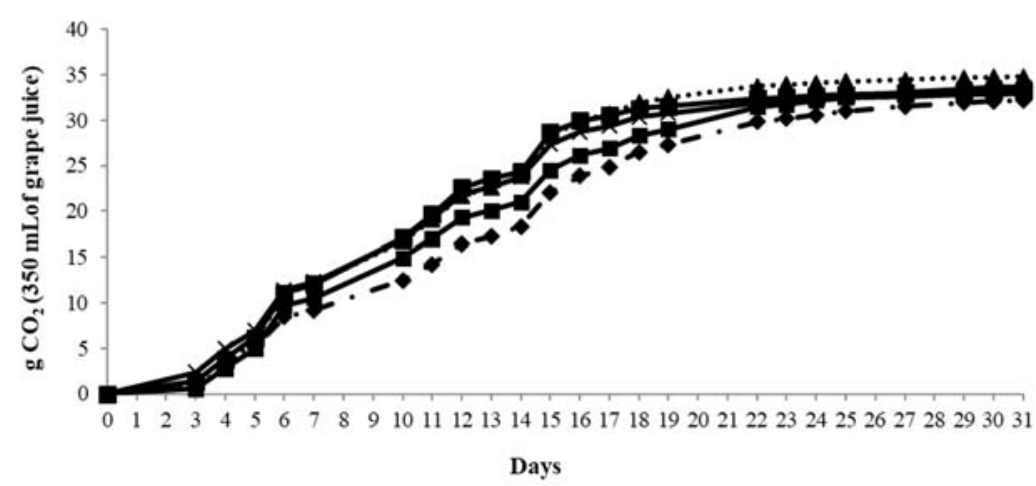

Figure 3. Fermentation kinetics of wines at two different temperature: (a) $22{ }^{\circ} \mathrm{C}$; and (b) $16{ }^{\circ} \mathrm{C}(\mathrm{OKAY}$

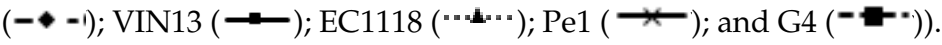

\subsection{Main Analytical Characteristics}

To evaluate the main analytical characteristics, two sets of microfermentation trials at $16{ }^{\circ} \mathrm{C}$ and $22{ }^{\circ} \mathrm{C}$ were carried out in Verdicchio natural grape juice. Three commercial strains, OKAY, EC1118 and VIN13, widely used in Piceno DOCG wines fermentation, were chosen as controls. Results shown in Table 2 indicated that the main analytical compounds did not generally show relevant differences among the strains. Only G4 strain showed a slight increase of volatile acidity $\left(0.64 \mathrm{~g} / \mathrm{L}\right.$ at $\left.22^{\circ} \mathrm{C}\right)$ while both indigenous yeasts exhibited a significant increase in glycerol production at $16^{\circ} \mathrm{C}$. A decrease of total $\mathrm{SO}_{2}$ production was seen for all strains at $22^{\circ} \mathrm{C}$.

\subsection{Main Volatile Compounds}

The evaluation of the main volatile compounds produced by S. cerevisiae strains revealed significant differences among the yeast cultures also strongly influenced by the fermentation temperature (Table 3).

The commercial strain OKAY at $22{ }^{\circ} \mathrm{C}$ showed significant higher production of esters such as ethyl butyrate, isoamyl acetate, phenyl ethyl acetate (supplementary material) and higher alcohols as $n$-propanol and $\beta$-phenyl ethanol (Table 3). At $22{ }^{\circ} \mathrm{C}, \mathrm{Pe} 1$ and G4 fermentation trials were characterized by high amounts of isoamyl acetate and in general of ethyl esters (ethyl hexanoate and ethyl octanoate). The other strains showed intermediate production of esters. EC1118 strain was characterized by a high production of acetaldehyde, isobutanol, amyl and isoamyl alcohols at both temperatures of fermentation $\left(22{ }^{\circ} \mathrm{C}\right.$ and $\left.16{ }^{\circ} \mathrm{C}\right)$. Moreover, at $16{ }^{\circ} \mathrm{C}$, EC1118 showed relevant and generalized enhancement of esters. In microfermentations carried out at $16^{\circ} \mathrm{C}$, some differences in esters and higher alcohols were found. With the exception of OKAY, the strains showed a generalized increase of esters at lower temperature. However, in Pe1 and G4 indigenous strains, there was a reduction of isoamyl acetate and a significant enhancement of phenyl ethyl acetate. Of particular relevance was the high production of acetaldehyde at both temperatures tested by EC1118 that could be negatively affect the analytical profile of white wines. 
Table 2. The main analytical characteristics of each S. cerevisiae strains on Verdicchio grape juice.

\begin{tabular}{|c|c|c|c|c|c|c|c|c|c|c|c|c|}
\hline \multirow[b]{2}{*}{ Strains } & \multicolumn{6}{|c|}{$22^{\circ} \mathrm{C}$} & \multicolumn{6}{|c|}{$16^{\circ} \mathrm{C}$} \\
\hline & $\begin{array}{l}\text { Ethanol } \\
(\% v / v)\end{array}$ & $\begin{array}{c}\text { Volatile } \\
\text { Acidity } \\
\text { (Acetic } \\
\text { Acid g/L) }\end{array}$ & $\begin{array}{c}\text { Glycerol } \\
\text { (g/L) }\end{array}$ & $\mathrm{SO}_{2}(\mathrm{mg} / \mathrm{L})$ & $\begin{array}{c}\text { Residual Sugar } \\
(\mathrm{g} / \mathrm{L})\end{array}$ & $\begin{array}{c}\text { Fermentation } \\
\text { Rate } \\
\text { (g CO} 2 / 3 \text { Days) }\end{array}$ & $\begin{array}{l}\text { Ethanol } \\
(\% v / v)\end{array}$ & $\begin{array}{c}\text { Volatile } \\
\text { Acidity } \\
\text { (Acetic } \\
\text { Acid g/L) }\end{array}$ & $\begin{array}{c}\text { Glycerol } \\
(\mathrm{g} / \mathrm{L})\end{array}$ & $\mathrm{SO}_{2}(\mathrm{mg} / \mathrm{L})$ & $\begin{array}{c}\text { Residual } \\
\text { Sugar }(g / L)\end{array}$ & $\begin{array}{l}\text { Fermentation } \\
\text { Rate } \\
\text { ( } \mathrm{g} \mathrm{CO}_{2} / 3 \text { Days) }\end{array}$ \\
\hline OKAY & $12.26 \pm 0.00^{\mathrm{a}}$ & $0.38 \pm 0.03^{b}$ & $4.77 \pm 0.39^{a}$ & $5.76 \pm 1.35^{\mathrm{ab}}$ & $0.04 \pm 0.00^{\mathrm{a}}$ & $6.97 \pm 1.36^{b}$ & $11.77 \pm 0.07 \mathrm{~b}, \mathrm{c}$ & $0.53 \pm 0.04^{a}$ & $4.56 \pm 0.08^{\mathrm{e}}$ & $14.12 \pm 1.30^{b}$ & $0.03 \pm 0.02^{\mathrm{a}}$ & $1.28 \pm 0.04^{b, c}$ \\
\hline VIN13 & $12.00 \pm 0.06^{\mathrm{a}}$ & $0.38 \pm 0.03^{b}$ & $3.81 \pm 0.05^{b}$ & $7.67 \pm 0.91^{\mathrm{a}}$ & $0.01 \pm 0.00^{c}$ & $7.97 \pm 0.46^{\mathrm{a}, \mathrm{b}}$ & $12.45 \pm 0.21^{\mathrm{a}}$ & $0.41 \pm 0.04^{b}$ & $5.47 \pm 0.13^{c}$ & $14.88 \pm 0.22 \mathrm{~b}$ & $0.01 \pm 0.00^{\mathrm{a}}$ & $1.39 \pm 0.34^{\mathrm{b}}$ \\
\hline EC1118 & $11.56 \pm 0.27^{b}$ & $0.44 \pm 0.03^{b}$ & $4.46 \pm 0.13^{\mathrm{a}}$ & $0.16 \pm 0.22^{c}$ & $0.01 \pm 0.01^{b, c}$ & $6.04 \pm 0.88^{\mathrm{b}}$ & $11.33 \pm 0.23^{c}$ & $0.38 \pm 0.01^{b}$ & $4.99 \pm 0.04^{d}$ & $16.39 \pm 0.09 \mathrm{a}, \mathrm{b}$ & $0.04 \pm 0.03^{a}$ & $0.71 \pm 0.19^{b, c}$ \\
\hline Pe1 & $11.96 \pm 0.05^{\mathrm{a}}$ & $0.40 \pm 0.05^{b}$ & $4.57 \pm 0.10^{\mathrm{a}}$ & $3.36 \pm 0.67^{b}$ & $0.04 \pm 0.01^{\mathrm{a}, \mathrm{b}}$ & $9.41 \pm 0.40^{\mathrm{a}}$ & $11.50 \pm 0.21 \mathrm{~b}, \mathrm{c}$ & $0.44 \pm 0.04^{b}$ & $6.42 \pm 0.12^{a}$ & $16.48 \pm 2.50^{\mathrm{a}, \mathrm{b}}$ & $0.02 \pm 0.01^{\mathrm{a}}$ & $2.37 \pm 0.46^{\mathrm{a}}$ \\
\hline G4 & $11.96 \pm 0.00^{\mathrm{a}}$ & $0.64 \pm 0.02^{a}$ & $4.93 \pm 0.07^{\mathrm{a}}$ & $9.44 \pm 2.94^{\mathrm{a}}$ & $0.02 \pm 0.02^{a, b, c}$ & $6.75 \pm 0.48^{b}$ & $11.92 \pm 0.11^{b}$ & $0.54 \pm 0.01 \mathrm{a}$ & $5.82 \pm 0.02^{b}$ & $18.56 \pm 0.45^{\mathrm{a}}$ & $0.01 \pm 0.00^{\mathrm{a}}$ & $0.57 \pm 0.19^{c}$ \\
\hline
\end{tabular}

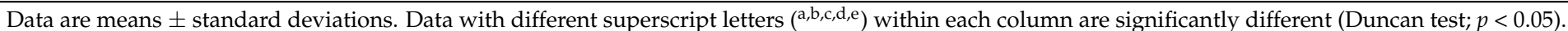

Table 3. The main volatile compounds of each S. cerevisiae strains on Verdicchio grape juice.

\begin{tabular}{|c|c|c|c|c|c|c|c|c|c|c|}
\hline Volatile Compounds $\left(\mathrm{mg} \mathrm{L}^{-1}\right)$ & & & $22{ }^{\circ} \mathrm{C}$ & & & & & $16^{\circ} \mathrm{C}$ & & \\
\hline Esters & OKAY & VIN13 & EC1118 & Pe1 & G4 & OKAY & VIN13 & EC1118 & Pe1 & G4 \\
\hline Ethyl acetate & $23.46 \pm 0.51^{\mathrm{b}}$ & $20.51 \pm 0.10^{c}$ & $33.25 \pm 0.01^{\mathrm{a}}$ & $14.47 \pm 0.33^{\mathrm{e}}$ & $16.74 \pm 0.15^{\mathrm{d}}$ & $25.53 \pm 0.15^{b}$ & $25.62 \pm 0.46^{b}$ & $31.03 \pm 0.37^{\mathrm{a}}$ & $15.92 \pm 0.12^{\mathrm{c}}$ & $15.95 \pm 0.53^{c}$ \\
\hline \multicolumn{11}{|l|}{ Alcohols } \\
\hline$n$-propanol & $40.54 \pm 0.20^{\mathrm{a}}$ & $18.41 \pm 0.16^{\mathrm{c}}$ & $19.62 \pm 0.06^{\mathrm{b}}$ & $13.76 \pm 0.04^{\mathrm{e}}$ & $15.705 \pm 0.20^{\mathrm{d}}$ & $41.70 \pm 0.24^{\mathrm{a}}$ & $24.58 \pm 0.01^{b}$ & $21.34 \pm 0.31^{c}$ & $16.00 \pm 0.49^{\mathrm{e}}$ & $19.95 \pm 0.56^{\mathrm{c}}$ \\
\hline Isobutanol & $5.166 \pm 0.17^{d}$ & $7.049 \pm 0.08^{c}$ & $13.681 \pm 0.02^{\mathrm{a}}$ & $6.777 \pm 0.20^{c}$ & $9.548 \pm 0.30^{\mathrm{b}}$ & $10.20 \pm 0.50^{b}$ & $7.41 \pm 0.37^{c}$ & $11.88 \pm 0.30^{\mathrm{a}}$ & $8.44 \pm 0.46^{\mathrm{c}}$ & $11.60 \pm 0.58^{\mathrm{a}}$ \\
\hline Amilyc alcohol & $13.35 \pm 0.05^{\mathrm{d}}$ & $14.70 \pm 0.31^{\mathrm{c}}$ & $18.82 \pm 0.53 \mathrm{a}$ & $11.45 \pm 0.02 \mathrm{e}$ & $16.71 \pm 0.04^{b}$ & $10.67 \pm 0.40^{c}$ & $12.34 \pm 0.30^{\mathrm{b}}$ & $10.77 \pm 0.07^{\mathrm{c}}$ & $12.43 \pm 0.51^{b}$ & $14.14 \pm 0.62^{a}$ \\
\hline Isoamilyc alcohol & $94.43 \pm 0.47^{c}$ & $96.04 \pm 0.40^{\mathrm{b}}$ & $105.49 \pm 0.30^{\mathrm{a}}$ & $80.38 \pm 0.48^{\mathrm{e}}$ & $82.54 \pm 0.25^{\mathrm{d}}$ & $74.55 \pm 0.37^{\mathrm{d}}$ & $80.82 \pm 0.74^{c}$ & $112.43 \pm 2.87^{a}$ & $61.91 \pm 0.59^{\mathrm{e}}$ & $88.64 \pm 0.36^{b}$ \\
\hline$\beta$-Phenyl ethanol & $34.95 \pm 7.02^{\mathrm{a}}$ & $11.32 \pm 0.32^{b}$ & $13.03 \pm 0.36^{\mathrm{b}}$ & $11.04 \pm 1.12^{b}$ & $12.13 \pm 0.77^{b}$ & $11.25 \pm 0.11^{\mathrm{c}}$ & $14.3 \pm 0.09^{b}$ & $16.7 \pm 0.05^{\mathrm{a}}$ & $10.82 \pm 0.01^{\mathrm{c}}$ & $13.2 \pm 0.03^{b}$ \\
\hline \multicolumn{11}{|l|}{ Carbonyl compounds } \\
\hline Acetaldehyde & $10.57 \pm 0.14^{\mathrm{e}}$ & $20.38 \pm 0.48^{d}$ & $91.33 \pm 0.29^{a}$ & $53.77 \pm 0.12^{b}$ & $32.355 \pm 0.24^{\mathrm{c}}$ & $13.07 \pm 0.44^{\mathrm{d}}$ & $19.56 \pm 0.40^{\mathrm{c}}$ & $134.901 \pm 0.80^{\mathrm{a}}$ & $30.86 \pm 2.67^{b}$ & $9.90 \pm 0.13^{\mathrm{d}}$ \\
\hline Acetoin & ND & ND & ND & ND & ND & ND & ND & ND & ND & ND \\
\hline
\end{tabular}

Data are means \pm standard deviations. Data with different superscript letters $\left({ }^{(a, b, c, d, e}\right)$ within each row are significantly different $($ Duncan test; $p<0.05)$. ND $=$ not detected 
The data on the volatile compounds were subjected to Principal Component Analysis (PCA) (Figure 4). The distribution of strains in the biplot graphic highlighted two main effects. PC2 grouped the strains in function of the fermentation temperature separating $16^{\circ} \mathrm{C}$ trials upper quadrants from the $22{ }^{\circ} \mathrm{C}$ trials (lower quadrants). Only Pe1 was placed close to the center. On the other hand, PC1 differentiated the strains in function of the volatile compounds assayed. At $22{ }^{\circ} \mathrm{C}$, indigenous strains were separated from the other strains mainly for isoamyl acetate production. At $16{ }^{\circ} \mathrm{C}$, all strains were separated for ethyl hexanoate with the exception of Pe1 strain.

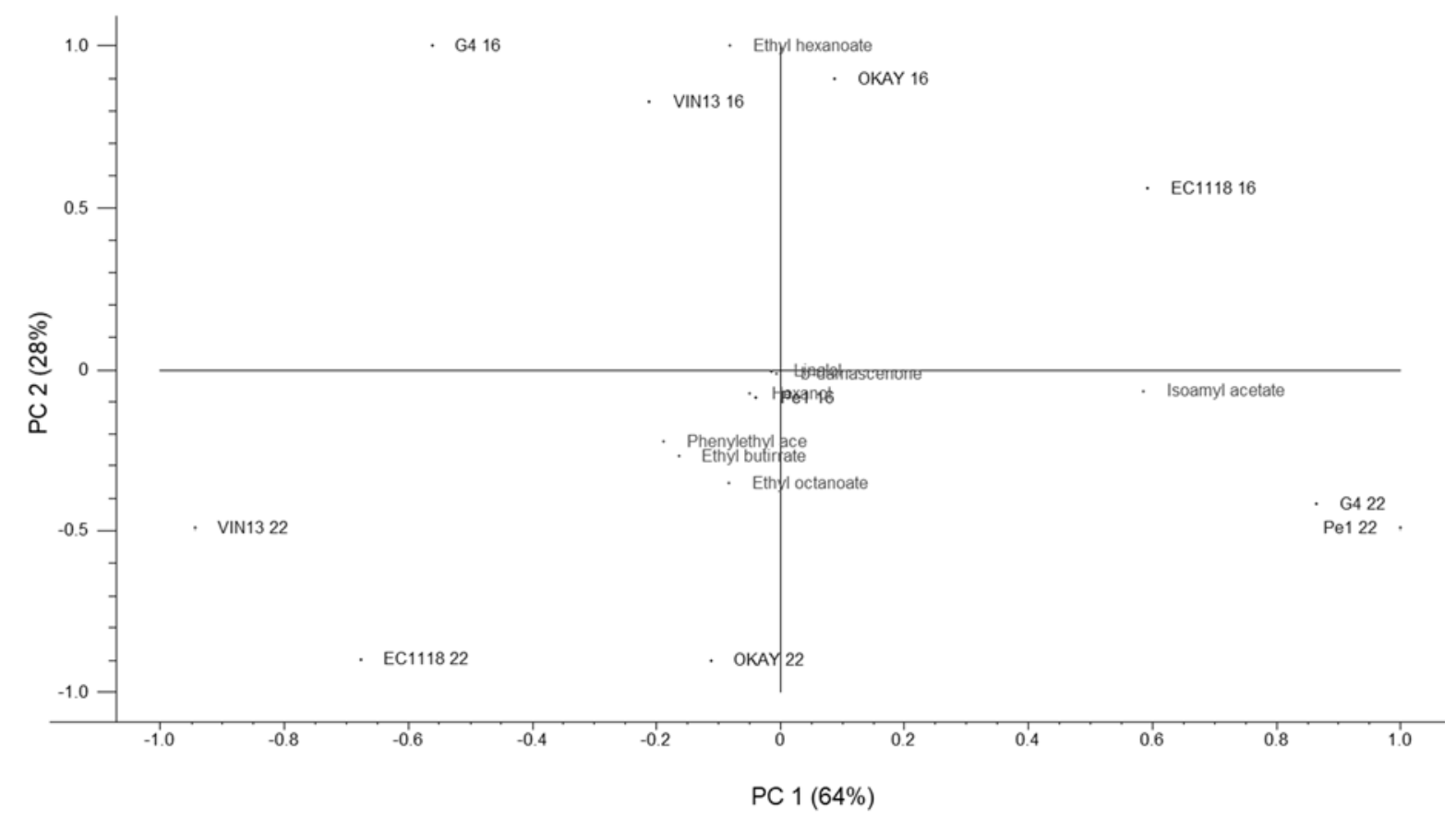

Figure 4. Principal component analysis based on the data for the volatile compounds in the wines produced by different $S$. cerevisiae strains. The numbers 16 and 22 associated to each strain refer to the fermentation temperature $\left(16^{\circ} \mathrm{C}\right.$ and $\left.22^{\circ} \mathrm{C}\right)$.

\section{Discussion}

In recent years, geographic distribution of microbial community of wine grapes has been investigated revealing regional microbial signatures and the geographic delineation of yeast communities with wines [21,22]. This distribution is conditioned by several factors such as cultivar, vintage and climate and could be influenced by agricultural practices $[15,23,24]$. In addition, preliminary evidence on the association of wine microbiome and phenotype at regional level suggests a microbial contribution to regional characteristic defined as "terroir" $[25,26]$. Indeed, there is preliminary evidence that yeast biota related to specific vineyard strongly influence the final wine composition [15,21,27-29]. Actually, the concept of the "indigenous" yeast is related to the preservation of microorganism naturally present in grapes and winery.

In this context, we evaluated the enological aptitude of two S. cerevisiae isolated from the regional winemaking areas Piceno DOC. The molecular characterization using the polymorphism of inter- $\delta$ regions showed specific patterns of selected S. cerevisiae strains isolated from Offida DOCG area in comparison with the most common S. cerevisiae commercial strains tested.

The same approach was used by Schuller et al. [30] to investigate the intraspecific genetic diversity of $S$. cerevisiae associated with the vineyard environment. To assess the oenological aptitude of two S. cerevisiae native Pe1 and G4 strains, microfermentations on natural grape juice were carried out. The influence of indigenous S. cerevisiae strains on the analytical and volatile compositions of wine 
was investigated for Montepulciano d'Abruzzo and Malvar winemaking areas. In both investigations, distinctive analytical profiles of wines were shown [31,32].

In this work, the two native strains Pe1 and G4 did not differ significantly from the compared commercial strains for the main analytical characteristics. On the other hand, they showed a specific volatile profile that could be useful to further characterize Piceno DOC wines, emphasizing their aromatic composition. In this regard, we found that the fermentation temperature plays an important role on flavor of final wine. Indeed, an increase of some volatile compounds, such as isoamyl acetate, ethyl hexanoate and ethyl octanoate, in microfermentations carried out at $22{ }^{\circ} \mathrm{C}$ was exhibited by two indigenous strains. Similarly, a reduction of total $\mathrm{SO}_{2}$ production was found at $22{ }^{\circ} \mathrm{C}$ in comparison with $16{ }^{\circ} \mathrm{C}$ fermentation trials without significant differences between the two indigenous and commercial starter strains.

In conclusion, the present work emphasizes the potential use of selected indigenous $S$. cerevisiae for the fermentation of Piceno DOC wines. In particular, these selected strains (Pe1 and G4) could be used as a suitable strategy to influence the aromatic complexity of Piceno DOC wines.

Supplementary Materials: Supplementary materials can be found at http:/ /www.mdpi.com/2311-5637/4/2/37/s1.

Author Contributions: A.A., L.C., M.C. and F.C. contributed equally to this manuscript. All authors participated in the design and discussion of the research. A.A. carried out the experimental part of the work. A.A., L.C., M.C. and F.C. carried out the analysis of the data and wrote the manuscript. All the authors have read and approved the final manuscript.

Acknowledgments: The authors thank Tenuta Cocci Grifoni di Guido Cocci Grifoni \& C. S.R.L. for the financial support of the research. We thank Paola Cocci Grifoni for her support.

Conflicts of Interest: The authors declare no conflicts of interest.

\section{References}

1. Consorziovinipiceni. Available online: http://www.consorziovinipiceni.com (accessed on 8 February 2018).

2. Padilla, B.; Gil, J.V.; Manzanares, P. Past and future of non-Saccharomyces yeasts: From spoilage microorganisms to biotechnological tools for improving wine aroma complexity. Front. Microbiol. 2016, 7, 411. [CrossRef] [PubMed]

3. Callejon, R.M.; Clavijo, A.; Ortigueira, P.; Troncoso, A.M.; Paneque, P.; Morales, M.L. Volatile and sensory profile of organic red wines produced by different selected autochthonous and commercial Saccharomyces cerevisiae strains. Anal. Chim. Acta 2010, 660, 68-75. [CrossRef] [PubMed]

4. Molina, A.M.; Swiegers, J.H.; Varela, C.; Pretorius, I.S.; Agosin, E. Influence of wine fermentation temperature on the synthesis of yeast-derived volatile aroma compounds. Appl. Microbiol. Biotechnol. 2007, 77, 675-687. [CrossRef] [PubMed]

5. Torija, M.J.; Beltran, G.; Novo, M.; Poblet, M.; Guillamo, J.M.; Mas, A.; Roze, N. Effects of fermentation temperature and Saccharomyces species on the cell fatty acid composition and presence of volatile compounds in wine. Int. J. Food Microbiol. 2003, 85, 127-136. [CrossRef]

6. Jolly, N.P.; Varela, C.; Pretorius, I.S. Not your ordinary yeast: Non-Saccharomyces yeasts in wine production uncovered. FEMS Yeast Res. 2014, 14, 215-237. [CrossRef] [PubMed]

7. Torrens, J.; Urpí, P.; Riu-Aumatell, M.; Vichi, S.; López-Tamames, E.; Buxaderas, S. Different commercial yeast strains affecting the volatile and sensory profile of cava base wine. Int. J. Food Microbiol. 2008, 124, 48-57. [CrossRef] [PubMed]

8. Álvarez-Pérez, J.M.; Campo, E.; San-Juan, F.; Coque, J.J.R.; Ferreira, V.; Hernández-Orte, P. Sensory and chemical characterization of the aroma of Prieto Picudo rosé wines: The differential role of autochthonous yeast strains on aroma profiles. Food Chem. 2012, 133, 284-292. [CrossRef] [PubMed]

9. Capece, A.; Granchi, L.; Guerrini, S.; Mangani, S.; Romaniello, R.; Vincenzini, M.; Romano, P. Diversity of Saccharomyces cerevisiae strains isolated from two Italian wine-producing regions. Front. Microbiol. 2016, 7, 1018. [CrossRef] [PubMed]

10. Capozzi, V.; Garofalo, C.; Chiriatti, M.A.; Grieco, F.; Spano, G. Microbial terroir and food innovation: The case of yeast biodiversity in wine. Microbiol. Res. 2015, 181, 75-83. [CrossRef] [PubMed] 
11. Schüller, D.; Casal, M. The use of genetically modified Saccharomyces cerevisiae strains in the wine industry. Appl. Microbiol. Biot. 2005, 68, 292-304. [CrossRef] [PubMed]

12. Tofalo, R.; Perpetuini, G.; Fasoli, G.; Schirone, M.; Corsetti, A.; Suzzi, G. Biodiversity study of wine yeasts belonging to the "terroir" of Montepulciano d'Abruzzo "Colline Teramane" revealed Saccharomyces cerevisiae strains exhibiting atypical and unique 5.8 S-ITS restriction patterns. Food Microbiol. 2014, 39, 7-12. [CrossRef] [PubMed]

13. Valero, A.; Marín, S.; Rarnos, A.J.; Sanchis, V. Ochratoxin A-producing species in grapes and sun-dried grapes and their relation to ecophysiological factors. Lett. Appl. Microbiol. 2005, 41, 196-201. [CrossRef] [PubMed]

14. Comitini, F.; Gobbi, M.; Domizio, P.; Romani, C.; Lencioni, L.; Mannazzu, I.; Ciani, M. Selected non-Saccharomyces wine yeasts in controlled multistarter fermentations with Saccharomyces cerevisiae. Food Microbiol. 2011, 28, 873-888. [CrossRef] [PubMed]

15. Bokulich, N.A.; Thorngate, J.H.; Richardson, P.M.; Mills, D.A. Microbial biogeography of wine grapes is conditioned by cultivar, vintage, and climate. Proc. Natl. Acad. Sci. USA 2014, 111, 139-148. [CrossRef] [PubMed]

16. Legras, J.L.; Karst, F. Optimisation of interdelta analysis for Saccharomyces cerevisiae strain characterisation. FEMS microbiol. Lett. 2003, 221, 249-255. [CrossRef]

17. EEC. Council Regulation 2870/00 laying down Community reference methods for the analysis of spirit drinks. Off. J. Eur. Comm. 2000, L333, 20-46.

18. Dukes, B.C.; Butzke, C.E. Rapid determination of primary amino acids in grape juice using an o-phthaldialdehyde/Nacetyl-L-cysteine spectrophotometric assay. Am. J. Enol. Vitic. 1998, 49, 125-134.

19. Vigentini, I.; Barrera Cardenas, S.; Valdetara, F.; Faccincani, M.; Panont, C.A.; Picozzi, C.; Foschino, R. Use of native yeast strains for in-bottle fermentation to face the uniformity in sparkling wine production. Front. Microbiol. 2017, 8, 1225. [CrossRef] [PubMed]

20. Canonico, L.; Comitini, F.; Ciani, M. Influence of vintage and selected starter on Torulaspora delbrueckii/Saccharomyces cerevisiae sequential fermentation. Eur. Food Res. Technol. 2015, 241, 827-833. [CrossRef]

21. Gayevskiy, V.; Goddard, M.R. Geographic delineations of yeast communities and populations associated with vines and wines in New Zealand. ISME J. 2012, 6, 1281. [CrossRef] [PubMed]

22. Taylor, J.W.; Turner, E.; Townsend, J.P.; Dettman, J.R.; Jacobson, D. Eukaryotic microbes, species recognition and the geographic limits of species: Examples from the Kingdom Fungi. Philos. Trans. R. Soc. Lond. B Biol. Sci. 2006, 361, 1947-1963. [CrossRef] [PubMed]

23. Milanović, V.; Comitini, F.; Ciani, M. Grape berry yeast communities: Influence of fungicide treatments. Int. J. Food Microbiol. 2013, 161, 240-246. [CrossRef] [PubMed]

24. Vigentini, I.; De Lorenzis, G.; Fabrizio, V.; Valdetara, F.; Faccincani, M.; Panont, C.A.; Foschino, R. The vintage effect overcomes the terroir effect: A three year survey on the wine yeast biodiversity in Franciacorta and Oltrepò Pavese, two northern Italian vine-growing areas. Microbiology 2015, 161, 362-373. [CrossRef] [PubMed]

25. Bokulich, N.A.; Lewis, Z.T.; Boundy-Mills, K.; Mills, D.A. A new perspective on microbial landscapes within food production. Curr. Opin. Biotechnol. 2016, 37, 182-189. [CrossRef] [PubMed]

26. Knight, S.; Klaere, S.; Fedrizzi, B.; Goddard, M.R. Regional microbial signatures positively correlate with differential wine phenotypes: Evidence for a microbial aspect to terroir. Sci. Rep. 2015, 5, 14233. [CrossRef] [PubMed]

27. Knight, S.; Goddard, M.R. Quantifying separation and similarity in a Saccharomyces cerevisiae metapopulation. ISME J. 2015, 9, 361-370. [CrossRef] [PubMed]

28. Lopandic, K.; Gangl, H.; Wallner, E.; Tscheik, G.; Leitner, G.; Querol, A.; Borth, N.; Breitenbach, M.; Prillinger, H.; Tiefenbrunner, W. Genetically different wine yeasts isolated from Austrian vine-growing regions influence wine aroma differently and contain putative hybrids between Saccharomyces cerevisiae and Saccharomyces kudriavzevii. FEMS Yeast Res. 2007, 7, 953-965. [CrossRef] [PubMed]

29. Taylor, M.W.; Tsai, P.; Anfang, N.; Ross, H.A.; Goddard, M.R. Pyrosequencing reveals regional differences in fruit-associated fungal communities. Environ. Microbiol. 2014, 16, 2848-2858. [CrossRef] [PubMed] 
30. Schüller, D.; Casal, M. The genetic structure of fermentative vineyard-associated Saccharomyces cerevisiae populations revealed by microsatellite analysis. Antonie Van Leeuwenhoek 2007, 91, 137-150. [CrossRef] [PubMed]

31. Cordero-Bueso, G.; Esteve-Zarzoso, B.; Gil-Díaz, M.; García, M.; Cabellos, J.M.; Arroyo, T. Improvement of Malvar wine quality by use of locally-selected Saccharomyces cerevisiae strains. Fermentation 2016, $2,7$. [CrossRef]

32. Suzzi, G.; Arfelli, G.; Schirone, M.; Corsetti, A.; Perpetuini, G.; Tofalo, R. Effect of grape indigenous Saccharomyces cerevisiae strains on Montepulciano d'Abruzzo red wine quality. Food Res. Int. 2012, 46, $22-29$. [CrossRef] 